\title{
SEÇİLMİ̧ ENDOJEN LAKTİK STARTER KÜLTÜRLER İLE TURŞU ÜRETİMİ
}

\author{
Mehmet Tokatlı,*, Simel Bağder Elmaci², Nurdan Arslankoz İşleyen ${ }^{3}$, Filiz Özçelik ${ }^{2}$ \\ ${ }^{1}$ Tokat Gaziosmanpaşa Üniversitesi, Mühendislik ve Doğa Bilimleri Fakültesi, Gıda Mühendisliği Bölümü, Tokat, \\ Türkiye \\ ${ }^{2}$ Ankara Üniversitesi, Mühendislik Fakültesi, Gıda Mühendisliği Bölümü, Ankara, Türkiye \\ ${ }^{3}$ Bolu Abant İzzet Baysal Üniversitesi, Yeniçağa Yaşar Çelik Meslek Yüksekokulu, Bolu, Türkiye
}

Geliş / Received: 24.05.2019; Kabul / Accepted: 01.07.2019; Online bask1 / Published online: 26.07.2019

Tokatlı, M., Bağder Elmacı, S., Arslankoz İşleyen, N., Özçelik, F. (2019). Seçilmiş endojen laktik starter kültürler ile turşu üretimi. GIDA (2019) 44 (4): 742-757 doi: 10.15237/gida.GD19081

Tokatli, M., Bagder Elmaci, S., Arslankoz Isleyen, N., Ozcelik, F. (2019). Pickle production by selected indigenous lactic starter cultures. GIDA (2019) 44 (4): $742-757$ doi: 10.15237/gida.GD19081

\section{ÖZ}

Bu çalışmada, turşu üretiminde kullanılabilecek starter kültürler geliştirmek amacı ile, seçilmiş endojen (yerel) Lactobacillus plantarum (MF513, MF377, MF213) ve L. plantarum MF513-Pediococcus ethanolidurans MF179 karışım suşları starter kültür olarak kullanılmış; fermantasyon süresince ve 6 aylık depolama aşamasında turşuların kimyasal, mikrobiyolojik, duyusal özellikleri değerlendirilmiştir. Starter kültürlerin fermantasyon sonuna kadar stabilitelerini koruyup koruyamadıklant, saf kültürlerin fermantasyonun başlangıcı ve bitimindeki hücre protein profilleri (SDS-PAGE) karşılaştırılarak belirlenmiştir. Karışık kültür kullanılarak üretilen turşularda en yüksek asitlik değerine (\% 0.87) fermantasyonun 20. gününde ulaşıldığı belirlenmiş ve $\mathrm{pH}$ değeri 3.26 olarak ölçülmüştür. Kontrol örneğinde asitlik artışı starter kullanılan turşu örneklerine kıyasla daha yavaş gerçekleşmiştir. L. plantarum suşlarının fermantasyon sonuna kadar stabilitelerini korudukları ve ortamdaki baskın mikroorganizmalar oldukları belirlenmiştir. Depolama sonrası en yüksek laktik asit $(1.62 \mathrm{~g} / 100 \mathrm{~mL})$ ve en düşük etil alkol $(0.26 \mathrm{~g} / 100 \mathrm{~mL})$ miktarı MF513-MF179 suşlarının kullanıldığı turşu örneğinde ölçülmüştür.

Anahtar kelimeler:Turşu, Laktik asit bakterisi, Starter kültür, Lactobacillus plantarum, Pediococcus ethanolidurans

\section{PICKLE PRODUCTION BY SELECTED INDIGENOUS LACTIC STARTER CULTURES}

\begin{abstract}
In this study, in order to develop starter cultures suitable for pickle production, the selected indigenous cultures of Lactobacillus plantarum (MF513, MF377, MF213) and mixed cultures of L. plantarum MF513Pediococcus ethanolidurans MF179 were used as starter cultures. The chemical, microbiological and sensory properties of pickles were monitored during fermentation and 6 months of storage. In order to determine whether the starter cultures preserved their stability until the end of fermentation, the cell protein profiles (SDS-PAGE) of pure cultures before fermentation were compared with that of after fermentation. The highest acidity $(0.87 \%)$ was found to be reached in the pickles produced by the addition of mixed starter cultures at the 20th day of fermentation and the $\mathrm{pH}$ value was measured as 3.26 . The acidity increase was slower in control samples as compared with the starter culture-added pickle samples. It was determined that $L$. plantarum strains preserved their stability until the end of fermentation and were predominant microorganisms in the environment. After storage, the highest lactic acid $(1.62 \mathrm{~g} / 100 \mathrm{~mL})$ and the lowest ethanol $(0.26 \mathrm{~g} / 100 \mathrm{~mL})$ content was observed in the pickle samples inoculated with MF513-MF179 strains.
\end{abstract}

Keywords:Pickle, lactic acid bacteria, starter culture, Lactobacillus plantarum, Pediococcus ethanolidurans

* Yazışmalardan sorumlu yazar/Corresponding author;

$\triangle$ mehmet.tokatli@gop.edu.tr $\quad$ (O+90 (356) 2521616 / 2887 


\section{GİRİ̧}

Meyve ve sebzelerin laktik asit fermantasyonu ile muhafaza edilmesi çok eski yllardan bu yana uygulanan, bir gıda koruma yöntemidir. Laktik asit bakterileri (LAB) tarafından gerçekleştirilen laktik asit fermantasyonu sonucu üretilen fermente gida ürünleri arasında turşu önemli bir yere sahiptir (Tokatlı vd., 2012). Turşu üretiminde kullanılan hıyar, lahana, yeşil biber gibi bitki kökenli substratların doğal mikroflorasında, laktik asit fermantasyonunu gerçekleştiren LAB'nin yanı sıra Pseudomonas, Erwinia ve Enterobacter türlerine ait bozulma yapan aerobik bakteriler, maya ve küfler gibi arzu edilmeyen mikroorganizmalar da yer almaktadır. LAB'nin taze hammaddedeki başlangıç sayıları da diğer mezofilik mikroorganizmalara kiyasla düşüktür (Breidt vd., 2013). Fermente sebzelerde, süt fermantasyonlarında olduğu gibi hammaddedeki istenmeyen endojen mikrofloray1 pastörizasyon yolu ile inhibe etmek mümkün olmamaktadır. Ancak, fermantasyonun başlangıcında sayıları oldukça düşük olan LAB, yüksek tuz konsantrasyonu, yüksek asitlik ve düşük $\mathrm{pH}$ $(<4.5)$ ile karakterize edilen turşunun ekstrem koşullarına dayanabildiklerinden, endojen mikroflorayla rekabete girerek ortama hakim olurlar. Bu zorlu ortam koşullannnda koliform grubu bakteriler, Pseudomonas, Bacillus, Clostridium ve $\mathrm{LAB}$ dışındaki diğer mikroorganizmalar inhibe olurlar (Hutkins, 2006). Turşu üretiminde LAB'nin ortama hakim olması için su aktivitesi, sicaklık, anaerobik ortam, tuz konsantrasyonu ve asitlik gibi uygun çevresel koşullar ayarlanırken, istenmeyen mikroorganizmaların gelişimi engellenmiş olur (Erten vd., 2016). Endojen LAB ve diğer mikrobiyel flora çevresel faktörlere bağl1 olarak değiştiğinden, sebze fermantasyonlarının kontrolü zordur. $\mathrm{Bu}$ nedenle, kontrolsüz koşullarda gerçekleşen spontan fermantasyon son ürünün kalitesi, duyusal özellikleri, güvenliği ve stabilitesinde farklıklara yol açabilmektedir (Gardner vd., 2001). Bu bağlamda, turşu üretiminde kullanılacak uygun starter kültürlerin geleneksel turşulardan izole edilen endojen (yerel) $\mathrm{LAB}$ arasından seçilmesi, bu endojen suşların, farklı kaynaklardan izole edilen endüstriyel starter kültürlere kıyasla, turşunun zorlu çevresel koşullarına daha iyi adapte olabilmeleri ve kolaylikla floraya hakim olabilmeleri nedeniyle oldukça önemlidir. Bu şekilde, geleneksel fermente ürünün karakteristik duyusal özelliklerini koruyarak, güvenli ve standart kalitede turşu üretimi mümkün olmaktadır (Tokatlı vd., 2017).

Ülkemizde Ankara-Çubuk bölgesi geleneksel yöntemlerle üretilen turşularıyla ünlüdür. Turşu Türk mutfağının vazgeçilmez ürünlerinden biri olmakla birlikte, üretimi halen küçük ölçekli işletmeler ile sınırlı olup, spontan fermantasyona dayalı olarak üretilmektedir. Büyük üretim potansiyeline rağmen, standart kalitede ürünler elde etmek mümkün olmamaktadır. Ürün standardizasyonu için, seçilen starter kültürlerin standart hammadde ve standart üretim tekniği ile birlikte kullanılması gerekmektedir. Turşu üretimi için uygun starter kültürlerin seçilmesi (Çon ve Karasu, 2009; Karasu vd., 2010) ve turşu üretiminde kullanılması (Çetin, 2011) üzerine az sayıda çalışma bulunmaktadır. Bu çalışmanın amac1, turşu üretiminde kullanılabilecek bir starter kültür geliştirmektir. Bu bağlamda, daha önceki çalışmalar ile Ankara Çubuk ilçesinden temin edilen geleneksel turşularından izole edilerek, moleküler tekniklerle tanımlanmış (Bağder Elmacı vd., 2015) endojen LAB arasindan teknolojik (Tokatlı vd., 2017) ve fonksiyonel özelliklerine (Tokatlı vd., 2015) göre seçilmiş 4 farklı bakteri kültürü starter olarak kullanılarak pilot ölçekte hıyar turşuları üretilmiş ve depolanmıştır. Üretilen turşular kimyasal, mikrobiyolojik ve duyusal açıdan incelenmiştir.

\section{MATERYAL VE YÖNTEM}

\section{Starter Kültürler}

Çalışmada starter kültür olarak kullanılan endojen Lactobacillus plantarum MF513 (erişim no: KJ855887), L. plantarum MF377 (erişim no: KJ994374), L. plantarum MF213 (erişim no: KJ994430) ve Pediococcus ethanolidurans MF179 (erişim no: KJ994445) suşlar1 daha önceki çalışmada Ankara-Çubuk yöresinde üretilen turşulardan izole edilmiş olup, moleküler yöntemlerle tanımlanmış (Bağder Elmacı vd., 2015), teknolojik (Tokatlı vd., 2017) ve fonksiyonel (Tokatlı vd., 2015) özellikleri belirlenmiştir. Ankara Üniversitesi Gıda 
Mühendisliği Bölümü Kültür Koleksiyonunda muhafaza edilen suşların 16S rRNA gen dizi analiz sonuçlarına ait GenBank erişim numaraları daha önceki çalışmada belirtilmiştir (Bağder Elmac1 vd., 2015).

\section{Turşu Üretimi}

Teknolojik ve fonksiyonel özellikleri açısından önemli bulunan LAB suşları (L. plantarum MF513, L. plantarum MF377, L. plantarum MF213 ve $P$. ethanolidurans MF179) starter kültür olarak seçilerek turşu denemelerinde kullanılmıştır. Bu amaçla, Çubuk Bölgesinden temin edilen turşuluk hiyarlar kullanılmıştır. Fermantasyon denemeleri, kapağı açılmadan örnek almaya olanak sağlayan, özel örnek alma düzeneğine sahip $3 \mathrm{~L}$ hacimli cam kavanozlarda gerçekleştirilmiştir. Hasadı izleyen 8-10 saat içerisinde laboratuvara getirilen hiyarlar, öncelikle şebeke suyu ile y1kanarak toz, çamur gibi kirliliklerinden arındırılmış ve klor çözeltisi içerisinde 15 dakika bekletildikten sonra, steril kaynak suyu ile yıkanarak klor uzaklaştırılmıştır. Bu şekilde hazırlanan $1.5 \mathrm{~kg}$ hıyar, $1.5 \mathrm{~kg}$ salamura (\% 8 tuz, \% 0.4 asetik asit, \% $0.4 \mathrm{CaCl}_{2}, \% 2$ glikoz) ile birlikte 3 L'lik fermantasyon kaplanna doldurulmuştur.

Fermantasyon denemelerinde; L. plantarum MF513, L. plantarum MF377, L. plantarum MF213 ve L. plantarum MF513-P. ethanolidurans MF179'in karışık kültürü ile \% 5 oranında aşılanmış ve kontrol amacıyla bakteri aşılanmamış örnekler olmak üzere 5 farklı turşu örneği, $28^{\circ} \mathrm{C}$ 'de sıcaklık kontrollü karanlık bir odada 3 tekerrürlü olarak fermantasyona uğratılmıştır. Starter kültür isimleri bu metinde turşu örneğinin ismi olarak kullanılmıştır. 20 günlük fermantasyon süresince ortaya çıan kimyasal ve mikrobiyolojik değişiklikler izlenmiştir. Fermantasyon bitiminde kimyasal ve mikrobiyolojik analizlere ek olarak, hıyar turşularında duyusal analiz ve starter kültür stabilite testleri yapilmıştır.

\section{Depolama}

Turşu depolama denemeleri de fermantasyon denemeleri ile aynı anda başlatılmış olup, denemeler 1L hacimdeki hermetik kapaklı cam kavanozlarda ve benzer dolum oranına göre hazırlanmış salamura ile gerçekleştirilmiştir.
Depolama süresince 2., 4. ve 6. aylarda alınan örneklerde kimyasal ve mikrobiyolojik analizler yapılmışır. Ayrıca, depolama sonunda (6. ay) turşu örneklerinde organik asit, şeker dağılımları ve etil alkol miktarları kromatografik (HPLC) olarak belirlenmiştir. Denemeler 3 tekerrürlü olarak yapılmıştır.

\section{Mikrobiyolojik Analizler}

Salamura örneklerinde toplam mezofilik aerobik bakteri sayımı (TMAB), Plate Count Agar (PCA) besiyerinde yayma kültürel sayım yöntemine göre, $30{ }^{\circ} \mathrm{C}$ 'de 48 saat inkübasyon ile; toplam LAB sayımı, yayma kültürel sayım yöntemi kullanılarak De Man-Rogosa-Sharpe (MRS) Agar besiyerinde $30{ }^{\circ} \mathrm{C}$ 'de 72 saat inkübasyon ile; toplam maya-küf sayımı Yeast Extract Glucose Chloramphenicol Agar (YGC) besiyerinde yayma kültürel sayım yöntemine göre $30^{\circ} \mathrm{C}$ 'de 96 saat inkübasyon ile; toplam Enterobacteriaceae sayımı \% 1 oraninda glikoz ilave edilmiş Violet Red Bile Agar (VRBA) besiyerinde yayma kültürel sayım yöntemine göre $37{ }^{\circ} \mathrm{C}$ 'de 18-24 saat inkübasyon ile yapılmışır (Gürgün ve Halkman, 1988). İnkübasyonların süresi sonunda canlı hücre sayımı yapılarak, sonuçlar log kob/mL olarak belirtilmiştir.

\section{Kimyasal Analizler}

Salamuraların $\mathrm{pH}$ değeri, potansiyometrik olarak, pH-metre (Mettler Toledo, S-20K, İsviçre) ile 20 ${ }^{\circ} \mathrm{C}$ 'de ölçülmüştür. Salamura örneklerinde titrasyon asitliği $0.01 \mathrm{~N} \mathrm{NaOH}$ (Merck, Germany) çözeltisiyle fenolftalein indikatörü $(\% 0.1 \mathrm{~g} / \mathrm{mL})$ eşliğinde belirlenerek g laktik asit/100 mL olarak ifade edilmiştir. Tuz miktarı ise, Mohr yöntemi esas alınarak örneklerin $0.1 \mathrm{~N} \quad \mathrm{AgNO}_{3}$ ile potasyum dikromat $\left(\begin{array}{lll}\% & 5 & \mathrm{~g} / \mathrm{mL}\end{array}\right)$ indikatörü eşliğinde titrasyonu ile belirlenmiş ve sonuçlar $g$ $\mathrm{NaCl} / 100 \mathrm{~mL}$ olarak verilmiştir. Salamura örneklerinde indirgen şeker tayini DNS (3.5Dinitrosalisilik asit) kullanılarak, Miller yöntemine göre yapılmışır (Forouchi ve Gunn, 1983).

Depolama denemelerinin sonunda (6. ay) alınan salamura örneklerinde organik asit, şeker dağılımını ve alkol içeriklerini belirlemek amacı ile; salamura örnekleri santrifüj edilmiş ve membran filtreden (Millipore Millex-HV Hydrophilic PVDF) geçirilerek sıvı faz HPLC cihazı için 
hazırlanmıştır. Analiz için Shimadzu HPLC, Japan (SCL 10 AVP sistem kontrol ünitesi, RID 10A dedektör, LC 10AD Vp pompa, CTO 10AS Vp kolon firın, Class Vp software, DGU 14A degazör, ICSep KE-COREGEL 87H3 kolon, ICSep COREGEL $87 \mathrm{H}$ guard kit) cihaz1 kullanılmıştır. Analiz için saf su mobil faz olarak kullanılarak $20 \mu \mathrm{L}$ örnek enjeksiyonu yapılmışır. Standart çözeltiler ise glikoz, fruktoz, etanol, asetik asit ve laktik asit ile hazırlanmıştır (Tomlins vd., 1990).

\section{Duyusal analiz}

Fermantasyon sonunda hiyar turşularında, 18-20 panelist tarafindan görünüş, renk, koku, lezzet, sertlik ve genel beğeni parametreleri esas alınarak ve 1-5 aralığında puanlama kullanılarak duyusal değerlendirmeleri yapılmıştır (Shinagawa vd., 1997).

\section{Starter kültür stabilite testi}

L. plantarum MF513, L. plantarum MF377, L. plantarum MF213 ve P. ethanolidurans MF179 starter kültürleri kullanılarak gerçekleştirilen 3 tekerrürlü fermantasyon denemeleri sonucunda, fermantasyonun bitiminden sonra salamura örneklerinden yayma plak yöntemine göre MRS katı besiyerine ekim yapılmıştır. Katı besiyeri üzerinde oluşan kolonilerden rastgele 20 adet saf kültür seçilerek, bu bakterilerin salamuraya ilave edilen starter kültür olup olmadıkları, hücre protein profilleri (SDS PAGE elektroforez) incelenerek belirlenmiştir. LAB'nin moleküler düzeyde belirlenmesi için, Laemmli (1970) tarafindan belirtilen yöntem modifiye edilerek ve Sodium Dodecyl Sulfate PolyAcrylamide Gel Electrophoresis (SDS-PAGE) tekniği kullanilarak toplam hücre protein profilleri ortaya konmuştur. LAB'nin hücre proteinleri, farklı yöntemlerin kombine edilmesiyle izole edilmiştir (Angelis vd., 2001; Swida ve Binek, 2005; Kim ve Adachi, 2007). Elde edilen proteinler, poliakrilamid jelde yürütülerek oluşan protein bantları jel görüntüleme sisteminde (Gel Logic 200 Imaging System Kodak, USA) görüntülenerek ilgili starter kültürlere ait olup olmadıkları ortaya konmuştur.

\section{İstatistiksel değerlendirme}

Tekerrürlü olarak elde edilen analiz sonuçlarının ortalamaları alınarak standart sapmaları ile birlikte verilmiştir. Elde edilen verilerin istatistiksel değerlendirilmesi ve karşılaştırılması Minitab programinda (Minitab release 12.1, Minitab inc., 1998) two sample T-test, one-way (ANOVA) ve balanced (ANOVA) analizleri kullanilarak yapilmıştır.

\section{BULGULAR ve TARTIŞMA}

\section{Kimyasal ve Mikrobiyolojik Değişimler}

Toplam titrasyon asitliği ve $\mathrm{pH}$ değeri fermantasyonun seyrinin izlenmesi açısından önemli rol oynamaktadırlar. Özellikle homofermantatif LAB tarafindan gerçekleştirilen asit üretimi, salamuranın laktik asit cinsinden toplam asitliğini arttırmakta ve turşuda koruyucu görevi üstlenmesini sağlamaktadır. $\mathrm{pH}$ değerindeki azalma, asitlik oluşumunun ortaya çıkardığı bir sonuç olarak kendini göstermektedir (Daeschel ve Fleming, 1984).

Fermantasyon süresince kimyasal değişiklikler incelenecek olursa (Çizelge 1), fermantasyonların başlangicında salamura $\mathrm{pH}$ değerleri 3.91-4.11 aralı̆̆ında ölçülmüştür. Fermantasyonların başlangıcında salamuranın $\mathrm{pH}$ değerlerindeki düşüş, starter kültür kullanılmayan kontrol örneğinde daha yavaş bir hızla gerçekleşirken, daha sonra mikrobiyel aktivitedeki artsşa bağlı olarak hız kazanmıştır. Starter kültür kullanılan tüm örnekler fermantasyonun 7. gününden itibaren sabit $\mathrm{pH}$ değerlerine ulaşmış, daha sonraki günlerde $\mathrm{pH}$ 'da çok önemli bir değişim gözlenmemiştir. Kontrol örneğindeki $\mathrm{pH}$ düşüşü diğer örneklere kıyasla daha yavaş seyretmiştir. 20 günlük fermantasyon süresince en düşük $\mathrm{pH}$ değeri (pH 3.26) karışı starter kültürün kullanıldığ1 MF513-MF179 nolu örnekte ölçülmüştür. Kontrol ve MF213 nolu turşu örneklerinde ise fermantasyon en yüksek $\mathrm{pH}$ değerlerinde tamamlanmıştır $(P>0.05)$.

Turşu üretiminde salamuraların başlangıç $\mathrm{pH}$ 's1, salamuradan karbondioksit $\left(\mathrm{CO}_{2}\right)$ geçirilerek veya asetik asit eklenerek daha da azaltılabilir. Salamuranın düşük başlangıç $\mathrm{pH}$ değerine sahip olmas1, fermantasyon sirasinda oluşan fazla $\mathrm{CO}_{2}$ 'nin salınmasına, $\mathrm{LAB}$ 'nin seçilimine ve düşük $\mathrm{pH}$ değerlerine duyarlı enterobakterilerin inhibe edilmesine yardımcı olmaktadır. Laktik asit 
fermantasyonlarında toplam asitlikte meydana gelen artışa paralel olarak ortam $\mathrm{pH}$ değerlerindeki azalma derecesi, sistemin tamponlama kapasitesi ve fermantasyondaki mikroorganizmalar tarafindan yürütülen diğer biyokimyasal aktivitelerden önemli ölçüde etkilenmektedir. Turşu fermantasyonları $\mathrm{pH}$ 4.5'ten daha yüksek bir değerde tamamlanırsa, ürünlerin mikrobiyolojik açıdan stabilitesi bozulmaktadır. Diğer taraftan, özellikle hıyar turşularında Pichia ve Issatchenkia cinsi mayaların, birincil fermantasyon sırasında üretilen laktik asidi katabolize ederek $\mathrm{pH}$ 'da bir artışa neden olduğu da bilinmektedir (Peréz-Díaz vd., 2013). Kamdee vd. (2014), hardal bitkisinin doğal ve starter kültür (Weissella spp. ve L. fermentum) kullanarak gerçekleştirdikleri laktik asit fermantasyonu sonucunda, starter kullanilan örneklerde $\mathrm{pH}$ değerini 3.22-3.24 olarak, doğal fermantasyon ile üretilen ürünlerde ise 3.33-4.44 olarak daha yüksek değerlerde bulmuşlardır. Çon ve Karasu (2009), antagonistik starter kültürler ile üretimi gerçekleştirilen turşularda $\mathrm{pH}$ değerlerini 3.503.94 aralı̆̆ında ölçmüşlerdir. Fermente salatalık gibi benzer sebzeler hakkında literatürde bildirilen $\mathrm{pH}$ değerleri 3.1-3.5 aralığında olup, sonuçlar ile uyum içerisindedir (Montet vd., 2014).

Çizelge 1. Fermantasyon sürisince salamura örneklerinin $\mathrm{pH}$, asitlik, tuz ve indirgen şeker miktarları Table 1. The $p H$, acidity, salt and reducing sugar in brine samples during fermentation

\begin{tabular}{|c|c|c|c|c|c|c|}
\hline & \multirow[b]{2}{*}{ Günler } & \multicolumn{5}{|l|}{ Turșu örnekleri } \\
\hline & & kontrol & MF513 & MF377 & MF213 & MF513-MF179 \\
\hline \multirow{7}{*}{ 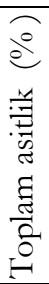 } & 1 & $0.23 \pm 0.00^{\mathrm{Ef}}$ & $0.29 \pm 0.00^{\mathrm{Ae}}$ & $0.24 \pm 0.01^{\mathrm{De}}$ & $0.27 \pm 0.01^{\mathrm{Ce}}$ & $0.28 \pm 0.01^{\mathrm{Bf}}$ \\
\hline & 4 & $0.48 \pm 0.00^{\mathrm{Ce}}$ & $0.63 \pm 0.02^{\mathrm{Ad}}$ & $0.50 \pm 0.01^{\mathrm{Cd}}$ & $0.60 \pm 0.02^{\mathrm{Bd}}$ & $0.61 \pm 0.01^{\mathrm{ABe}}$ \\
\hline & 7 & $0.55 \pm 0.01^{\mathrm{Cd}}$ & $0.67 \pm 0.01^{\mathrm{Acd}}$ & $0.61 \pm 0.03^{\mathrm{Bc}}$ & $0.62 \pm 0.01^{\mathrm{Bcd}}$ & $0.67 \pm 0.00^{\mathrm{Ad}}$ \\
\hline & 11 & $0.61 \pm 0.03^{\mathrm{Bc}}$ & $0.71 \pm 0.04^{\mathrm{Abc}}$ & $0.70 \pm 0.03^{\mathrm{Ab}}$ & $0.64 \pm 0.01^{\mathrm{Bc}}$ & $0.74 \pm 0.02^{\mathrm{Acd}}$ \\
\hline & 14 & $0.64 \pm 0.04^{\mathrm{Bbc}}$ & $0.73 \pm 0.04 \mathrm{Aab}$ & $0.76 \pm 0.02^{\mathrm{Aa}}$ & $0.65 \pm 0.01 \mathrm{Bbc}$ & $0.76 \pm 0.02^{\mathrm{Abc}}$ \\
\hline & 17 & $0.66 \pm 0.03^{\mathrm{Cab}}$ & $0.74 \pm 0.04^{\mathrm{Bab}}$ & $0.78 \pm 0.00^{\mathrm{ABa}}$ & $0.68 \pm 0.04 \mathrm{Cb}$ & $0.81 \pm 0.04^{\mathrm{Ab}}$ \\
\hline & 20 & $0.69 \pm 0.01^{\mathrm{Ca}}$ & $0.77 \pm 0.05^{\mathrm{Ba}}$ & $0.78 \pm 0.00^{\mathrm{Ba}}$ & $0.73 \pm 0.04^{\mathrm{BCa}}$ & $0.87 \pm 0.08^{\mathrm{Aa}}$ \\
\hline \multirow{7}{*}{$\stackrel{I}{D}$} & 1 & $4.30 \pm 0.00^{\mathrm{Aa}}$ & $3.91 \pm 0.02^{\mathrm{Da}}$ & $4.11 \pm 0.04^{\mathrm{Ba}}$ & $4.01 \pm 0.02^{\mathrm{Ca}}$ & $3.94 \pm 0.02^{\mathrm{Da}}$ \\
\hline & 4 & $3.63 \pm 0.01^{\mathrm{Ab}}$ & $3.45 \pm 0.03^{\mathrm{Bb}}$ & $3.59 \pm 0.02^{\mathrm{Ab}}$ & $3.49 \pm 0.04^{\mathrm{Bb}}$ & $3.47 \pm 0.01^{\mathrm{Bb}}$ \\
\hline & 7 & $3.53 \pm 0.03 \mathrm{Ac}$ & $3.37 \pm 0.04 \mathrm{Bc}$ & $3.44 \pm 0.04 \mathrm{Bc}$ & $3.42 \pm 0.03^{\mathrm{Bc}}$ & $3.39 \pm 0.01^{\mathrm{Bbc}}$ \\
\hline & 11 & $3.48 \pm 0.03^{\mathrm{Acd}}$ & $3.33 \pm 0.03^{\mathrm{Cc}}$ & $3.37 \pm 0.04^{\mathrm{BCcd}}$ & $3.43 \pm 0.02^{\mathrm{ABc}}$ & $3.32 \pm 0.01^{\mathrm{Cc}}$ \\
\hline & 14 & $3.46 \pm 0.04^{\mathrm{Acd}}$ & $3.33 \pm 0.03 \mathrm{Cc}$ & $3.35 \pm 0.03^{\mathrm{BCd}}$ & $3.41 \pm 0.02^{\mathrm{ABc}}$ & $3.30 \pm 0.01^{\mathrm{Cc}}$ \\
\hline & 17 & $3.44 \pm 0.03^{\mathrm{Ad}}$ & $3.33 \pm 0.02^{\mathrm{Bc}}$ & $3.34 \pm 0.03^{\mathrm{Bd}}$ & $3.41 \pm 0.02^{\mathrm{ABc}}$ & $3.26 \pm 0.06^{\mathrm{Bc}}$ \\
\hline & 20 & $3.44 \pm 0.03^{\mathrm{Ad}}$ & $3.34 \pm 0.02^{\mathrm{BCc}}$ & $3.34 \pm 0.03^{\mathrm{Cd}}$ & $3.43 \pm 0.03^{\mathrm{ABc}}$ & $3.26 \pm 0.06^{\mathrm{Cc}}$ \\
\hline \multirow{7}{*}{ 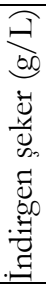 } & 1 & $25.89 \pm 0.27^{\mathrm{Aa}}$ & $24.05 \pm 0.24 \mathrm{Ca}$ & $25.73 \pm 0.73^{\mathrm{Aa}}$ & $24.26 \pm 0.43^{\mathrm{BCa}}$ & $25.31 \pm 0.39 \mathrm{ABa}$ \\
\hline & 4 & $19.41 \pm 1.04^{\mathrm{Bb}}$ & $21.72 \pm 0.63^{\mathrm{ABab}}$ & $23.48 \pm 1.70^{\mathrm{Aa}}$ & $21.12 \pm 0.13^{\mathrm{ABb}}$ & $21.12 \pm 0.08^{\mathrm{ABb}}$ \\
\hline & 7 & $14.14 \pm 1.48^{\mathrm{Ac}}$ & $18.39 \pm 2.03^{\mathrm{Abc}}$ & $18.00 \pm 2.10^{\mathrm{Ab}}$ & $18.59 \pm 1.97 \mathrm{Ab}$ & $15.09 \pm 0.82^{\mathrm{Ac}}$ \\
\hline & 11 & $4.96 \pm 0.25^{\mathrm{BCd}}$ & $16.54 \pm 2.25^{\mathrm{Ac}}$ & $3.10 \pm 1.85^{\mathrm{Cc}}$ & $8.06 \pm 1.05^{\mathrm{Bc}}$ & $3.63 \pm 0.45^{\mathrm{Cd}}$ \\
\hline & 14 & $1.85 \pm 0.22^{\mathrm{Be}}$ & $15.17 \pm 3.40^{\mathrm{Acd}}$ & $1.87 \pm 1.08^{\mathrm{Bc}}$ & $2.04 \pm 0.73^{\mathrm{Bd}}$ & $1.39 \pm 0.35^{\mathrm{Be}}$ \\
\hline & 17 & $0.99 \pm 0.38^{\mathrm{Be}}$ & $11.39 \pm 1.46^{\mathrm{Ade}}$ & $0.94 \pm 0.25^{\mathrm{Bc}}$ & $1.11 \pm 0.34 \mathrm{Bd}$ & $1.07 \pm 0.22^{\mathrm{Be}}$ \\
\hline & 20 & $0.79 \pm 0.14^{\mathrm{Be}}$ & $8.89 \pm 0.11^{\mathrm{Ae}}$ & $0.71 \pm 0.16^{\mathrm{Bc}}$ & $0.89 \pm 0.17 \mathrm{Bd}$ & $0.92 \pm 0.15^{\mathrm{Be}}$ \\
\hline \multirow{7}{*}{$\begin{array}{l}\stackrel{N}{\exists} \\
\stackrel{1}{\partial} \\
\partial^{\circ}\end{array}$} & 1 & $4.42 \pm 0.07 \mathrm{Aa}$ & $4.31 \pm 0.18^{\mathrm{Aa}}$ & $4.43 \pm 0.15^{\mathrm{Aa}}$ & $4.37 \pm 0.12^{\mathrm{Aa}}$ & $4.25 \pm 0.08^{\mathrm{Aa}}$ \\
\hline & 4 & $4.25 \pm 0.04^{\mathrm{Ab}}$ & $4.25 \pm 0.09 \mathrm{Aa}$ & $4.30 \pm 0.10^{\mathrm{Aa}}$ & $4.30 \pm 0.06^{\mathrm{Aa}}$ & $4.23 \pm 0.04^{\mathrm{Aa}}$ \\
\hline & 7 & $4.25 \pm 0.02^{\mathrm{Abc}}$ & $4.24 \pm 0.05^{\mathrm{Aa}}$ & $4.25 \pm 0.04^{\mathrm{Aa}}$ & $4.25 \pm 0.04^{\mathrm{Aa}}$ & $4.25 \pm 0.06^{\mathrm{Aa}}$ \\
\hline & 11 & $4.25 \pm 0.00^{\mathrm{Ac}}$ & $4.23 \pm 0.07^{\mathrm{Aa}}$ & $4.25 \pm 0.00^{\mathrm{Aa}}$ & $4.25 \pm 0.00^{\mathrm{Aa}}$ & $4.25 \pm 0.04^{\mathrm{Aa}}$ \\
\hline & 14 & $4.24 \pm 0.04^{\mathrm{Ac}}$ & $4.24 \pm 0.03^{\mathrm{Aa}}$ & $4.23 \pm 0.06^{\mathrm{Aa}}$ & $4.24 \pm 0.03^{\mathrm{Aa}}$ & $4.23 \pm 0.08^{\mathrm{Aa}}$ \\
\hline & 17 & $4.25 \pm 0.01 \mathrm{Ac}$ & $4.25 \pm 0.00^{\mathrm{Aa}}$ & $4.25 \pm 0.01^{\mathrm{Aa}}$ & $4.21 \pm 0.07 \mathrm{Aa}$ & $4.25 \pm 0.00^{\mathrm{Aa}}$ \\
\hline & 20 & $4.25 \pm 0.02^{\mathrm{Ac}}$ & $4.24 \pm 0.02^{\mathrm{Aa}}$ & $4.24 \pm 0.00^{\mathrm{Aa}}$ & $4.25 \pm 0.00^{\mathrm{Aa}}$ & $4.25 \pm 0.00^{\mathrm{Aa}}$ \\
\hline
\end{tabular}

*ABC: İstatistiksel olarak aynı satırdaki veriler arasındaki benzerlik $(P<0.05)$

**abc: İstatistiksel olarak aynı sütundaki veriler arasındaki benzerlik $(P<0.05)$ 
Fermantasyon süresince salamura örneklerinin toplam titrasyon asitliklerinde meydana gelen değişimler Çizelge 1'de verilmiştir. Fermantasyonun 1. gününde örneklerin titrasyon asitlikleri, salamuraya ilave edilen asetik asit kaynakl1 olarak \% $\quad 0.23-0.29$ arasinda bulunmuştur. Starter kültür kullanılmayan kontrol örneğinde asitlik gelişiminin $\mathrm{pH}$ değişiminde olduğu gibi daha yavaş gerçekleştiği görülmektedir. Starter kültür kullanılan turşu örnekleri fermantasyonun ilk günlerinde (1-7. gün) kontrol örneğine kıyasla daha hizlı asit oluşturmuşlardır. Ancak MF377 nolu turşu örneğinde fermantasyonun 4. gününe kadar asitlik artışının kontrol örneği ile benzer olduğu görülmektedir. Fermantasyon sırasında en yüksek titrasyon asitliği (\% 0.87) değerine karışı kültür kullanilan MF513-MF179 nolu örnekte fermantasyonun 20. gününde ulaşıldığ belirlenmiştir $(P<0.05)$. Asit oluşumu açısından fermantasyon sonunda karışı kültürün kullanıldığı turşularda en yüksek asitlik ve en düşük $\mathrm{pH}$ değerine ulaşıldığ gözlenmiştir. $\mathrm{Bu}$ durum, L. plantarum MF513 ve P. ethanolidurans MF179 suşlarının fermantasyon ortamında sinbiyotik çalışmalarının bir sonucu olarak daha verimli asit oluşumuna sebep olması ile ilişskilendirilmiştir. Tekli starter kültür kullanılarak üretilen salamura örneklerinin gerek $\mathrm{pH}$ gerekse toplam asitlik sonuçları incelendiğinde, sadece MF513 nolu turşu salamuralarının fermantasyon bitiminde yüksek asitlik değerlerine ulaştığ1 görülmektedir. Genel olarak turşu fermantasyonlarında L. plantarum türlerinin iyi bir asit üretici suş olduğu bilinmektedir (Nilchian vd., 2016). Bu durum, ayrica daha önce yapmış olduğumuz LAB'nin teknolojik özelliklerinin belirlenmesi ile ilgili çalışmada söz konusu $L$. plantarum MF513 suşunun iyi bir asit üreticisi olduğu sonucu ile de uyum içerisindedir (Tokatlı vd., 2017). Tüm örneklerde fermantasyon sonunda ulaşılan en yüksek titrasyon asitliği değerlerinin yapılan diğer çalışmalara kıyasla biraz düşük düzeylerde kaldığı belirlenmiştir. Yapılan bazı çalışmalarda ise benzer asitlik değerleri elde edilmiştir. Nilchian vd. (2016), hiyar turşusu ile yaptıkları çalışmada, starter kültür olarak $L$. plantarum, L. bulgaricus ve Streptococcus thermophilus suşlarını kullanarak gerçekleştirdikleri fermantasyonlarda son ürün asitlik değerini \% 0.45-0.63 aralığında bulmuşlar ve kontrol örneğine klyasla daha yüksek olduğunu belirtmişlerdir. Akpinar-Bayizit vd. (2007), starter kültür olarak L. plantarum, Leu. mesenteroides, L. brevis ve $P$. cereviseae suşlarını kullanarak ürettikleri havuç turşularında toplam asitlik değerini \% 0.890.92 olarak, starter kültür kullanilmadan üretilen kontrol turşu örneklerinde ise \% 0.77-0.83 olarak bulmuşlardır.

Salamuralarda bulunan indirgen şeker miktarı da, mikrobiyel populasyonun hızla çoğalmasına paralel şekilde fermantasyonun 1. gününden itibaren hızla azalmıştır (Çizelge 1). 1. gün salamura örneklerinde belirlenen indirgen şeker miktarlarındaki farklılığı ise aynı olgunluk derecesindeki hammaddenin kavanozlara eşit olarak dağılmamasından ve her kavanoz içerisindeki ilk 1 gün içerisinde farklı yoğunlukta bir mikrobiyel gelişme ortaya çıkmasından kaynaklandığı düşünülmektedir $\left(\begin{array}{ll}P & <0.05\end{array}\right)$. Fermantasyonun ilk gününde indirgen şeker miktarı 24.05-25.89 g/L aralığında saptanmıştır. Doğal fermantasyon yolu ile üretilen kontrol örneğinin 7. güne kadar indirgen şeker miktarındaki azalma çok hızlı gerçekleşmiş olup, bu durum asit üretim sonuçları ile uyumsuzluk sergilemiştir. Fermantasyonun ilk aşamasında kontrol örneğinin doğal florasinda bulunan mikroorganizmalar tarafindan kullanilan şekerlerin bir kısmının organik asitler dışında başka ürünlere dönüşümüne işaret etmektedir. Diğer taraftan, L. plantarum ve $P$. ethanolidurans suşları kullanılarak fermente edilen örnekte ise asitlik miktarlarındaki artışa paralel olarak indirgen şeker miktarının da hızla azaldığı görülmektedir. Fermantasyonun 11. gününe kadar kontrol, MF513-MF179, MF377, MF213 nolu örneklerde hızlı bir şekilde azalan indirgen şeker miktarı, bu günden sonra mikroorganizmalar tarafindan daha yavaş bir hızla tüketilmiştir. Fermantasyon sonunda kontrol, MF377, MF213 ve MF513MF179 nolu örneklerde düşük miktarda ve benzer $(0.71-0.92 \mathrm{~g} / \mathrm{L}) \quad$ indirgen şeker kaldığ görülmektedir $(P>0.05)$. Fermantasyon sonunda salamuralarda çok düşük seviyede indirgen şeker 
belirlenmesi, bu örneklerde fermantasyonun 17 günde tamamlandığını göstermektedir. Fermantasyon sonunda en yüksek indirgen şeker içeriği MF513 nolu turşu örneğinde $(8.89 \mathrm{~g} / \mathrm{L})$ belirlenmiştir (Çizelge 1). Starter kültürler, fermente olabilir şekerleri, metabolik yola bağlı olarak lezzet bileşenlerinin yanı sıra laktik aside, organik asitlere, $\mathrm{CO}_{2}$ ve alkole dönüştürmektedirler (Özer ve Yıldırım, 2018). L. plantarum suşları genellikle kalan şekerlerle fermantasyonun son aşamasinda neredeyse sadece laktik asit üretirler ve çok düşük pH'ları tolere etme yeteneklerine sahiptirler (Breidt vd, 2013). Ancak, MF513 nolu turşu örneğinde fermantasyonda yüksek asitlik verisine rağmen yüksek miktarda şekerin ortamda kalmış olması tam olarak açiklanamamakla birlikte, MF513 nolu turşuda enzimatik aktivite nedeniyle, fermantasyonun sonlarına doğru şekerlerin sebzelerden salamura ortamina difüzyonu ile ilişkili olabileceği düşünülmektedir (Gardner vd., 2001).

Denge noktasında \% $4 \mathrm{NaCl}$ içerecek şekilde hazırlanan salamuralarda tuz konsantrasyonu, fermantasyonun ilk gününde alınan örneklerde \% 4.43-4.25 olarak bulunmuştur (Çizelge 1). Kontrol ve MF513 nolu turşu örneklerinde 1. günden sonra, MF377 ve MF213 nolu örneklerde ise 4. günden itibaren tuz içeriği dengeye ulaşmıştır. Sonuç olarak, tüm örneklerin fermantasyon süresince ulaştıkları tuz denge noktası birbirine

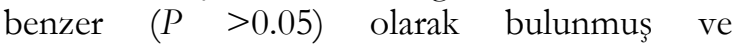
fermantasyon \% 4.25 tuz konsantrasyonunda tamamlanmıştır.

Starter kültürler ile üretimleri gerçekleştirilen turşu örneklerinin fermantasyon süresince mikrobiyolojik özelliklerinde meydana gelen değişimler Şekil 1'de verilmiş olup, incelendiğinde; starter kültür kullanılan MF513, MF377, MF213, MF513-MF179 nolu örneklerde, fermantasyonun ilk gününde yüksek oranda LAB ve toplam mezofil bakteri tespit edilmiş, en yüksek LAB sayıs1, sirasiyla MF513, MF513MF179, MF213, MF377 nolu örneklerde 8.48; 8.09; 8.06; $7.51 \log \mathrm{kob} / \mathrm{mL}$ olarak bulunmuştur. Kontrol örneğinde ise, toplam LAB say1s1 $4.01 \mathrm{log}$ $\mathrm{kob} / \mathrm{mL}$ olarak bulunmuştur. Benzer şekilde toplam mezofil bakteri say1s1 da, sirasiyla MF513,
MF513-MF179, MF213, MF377 nolu örneklerde yüksek değerlerde bulunmuştur. Toplam mezofil bakteri say1s1 ve toplam LAB say1s1, MF513 nolu örnek hariç tüm örneklerde 4. günde en yüksek değerine ulaşmış, daha sonraki günlerde giderek azalmıştır. Kamdee vd. (2014), starter kültür kullanarak gerçekleştirdikleri fermantasyonlarda başlangıç LAB yükünü 6.11-6.16 log kob/mL, kontrol örneğinde ise $5.58 \mathrm{log} \mathrm{kob} / \mathrm{mL}$ olarak bulmuşlardır. Fermantasyonun 4. gününden itibaren salamuralarda maya gelişmesi tespit edilmeye başlanmış ve sonraki fermantasyon süresince çok önemli değişimler olmadan fermantasyonu tamamlamı̧lardır. Nilchian vd. (2016), starter kültür kullanarak ürettikleri hıyar turşularında fermantasyonun 6. gününde toplam LAB, mezofil bakteri ve maya miktarlarını sırası ile $7.46,6.38$ ve $6.65 \mathrm{log} \mathrm{kob} / \mathrm{mL}$ olarak bildirmişlerdir. Fermente ürünlerde $\mathrm{pH}$ değerinin 4.5' in altına düşmesi birçok bozulma yapan bakteriler ve enterobakteriler için gelişmeyi sınırlayıc1 faktör olduğu bilinmektedir (Özer ve Yildırım, 2018). Fermantasyonun 1. günü tüm örneklerde rastlanan enterobakteriler ise 4 . günden itibaren sayılamamıştır. Bu durum asitlik gelişimine paralel olarak enterobakterilerin daha fazla gelişemedikleri şeklinde yorumlanmıştır. Kamda vd. (2015) yaptıkları çalışmada, starter olarak LAB karış1k kültürleri (L. plantarum UFLA $\mathrm{CH} 3, \quad P$. acidilactici UFLA BFFCX 27.1) kullanılarak üretilen fermente turşularda yüksek miktarda organik asit ve esterlerin üretimi sonucu enterobakter gelişiminin inhibe edildiği sonucuna ulaşmışlardır.

\section{Duyusal Değerlendirme}

Cizelge 2 incelendiğinde kontrol ve starter kültürlerin kullanıldığ tüm turşu örneklerinin görünüş ve koku puanları benzer bulunmuştur $(P$ $>0.05$ ). Kontrol gurubuna ait renk puanlaması ise starter kullanılan örneklerden daha düşük olarak değerlendirilmiştir $(P<0.05)$. MF213 nolu turşu örneğinin ise lezzet, sertlik ve genel beğeni olarak almış olduğu puanların diğer turşu örneklerine göre daha düşük kaldığ1 görülmektedir. Bu durum MF213 nolu turşu örneğinde fermantasyon sonuna doğru maya sayısında gözlenen artı̧̧ ile ilișkilendirilmiş ve artan maya popülasyonunun ürünün lezzet, sertlik ve genel beğeni puanlarına 
olumsuz yansıdığ1 sonucunu göstermektedir. Çoğu turşu fermantasyonlarında maya aktivitesindeki artış, pektolitik enzimler ve uçucu bileşiklerin miktarında artışa sebep olarak ürünlerin fiziksel ve duyusal kalitesini olumsuz etkilemektedir (Holzapfel, 2014). Diğer taraftan da bazı çalışmalarda bir miktar maya aktivitesinin ürünün kalitesine olumlu etkisinin bulunduğu belirtilmektedir (Wu vd., 2014). Duyusal değerlendirme sonuçları genel olarak değerlendirilecek olursa; starter kültür kullanılarak üretilen turşuların beğenilme oranı, starter kültür kullanılmadan doğal fermantasyon ile üretilen kontrol örneklerine kiyasla belirgin bir farklilık ortaya koymamıştır. Xia vd. (2017), L. brevis AR123 suşunu starter kültür olarak kullandıkları çalışmada spontan fermantasyon ile elde edilen ürünlere kıyasla duyusal açıdan daha iyi ürün elde ettiklerini bildirmişlerdir.

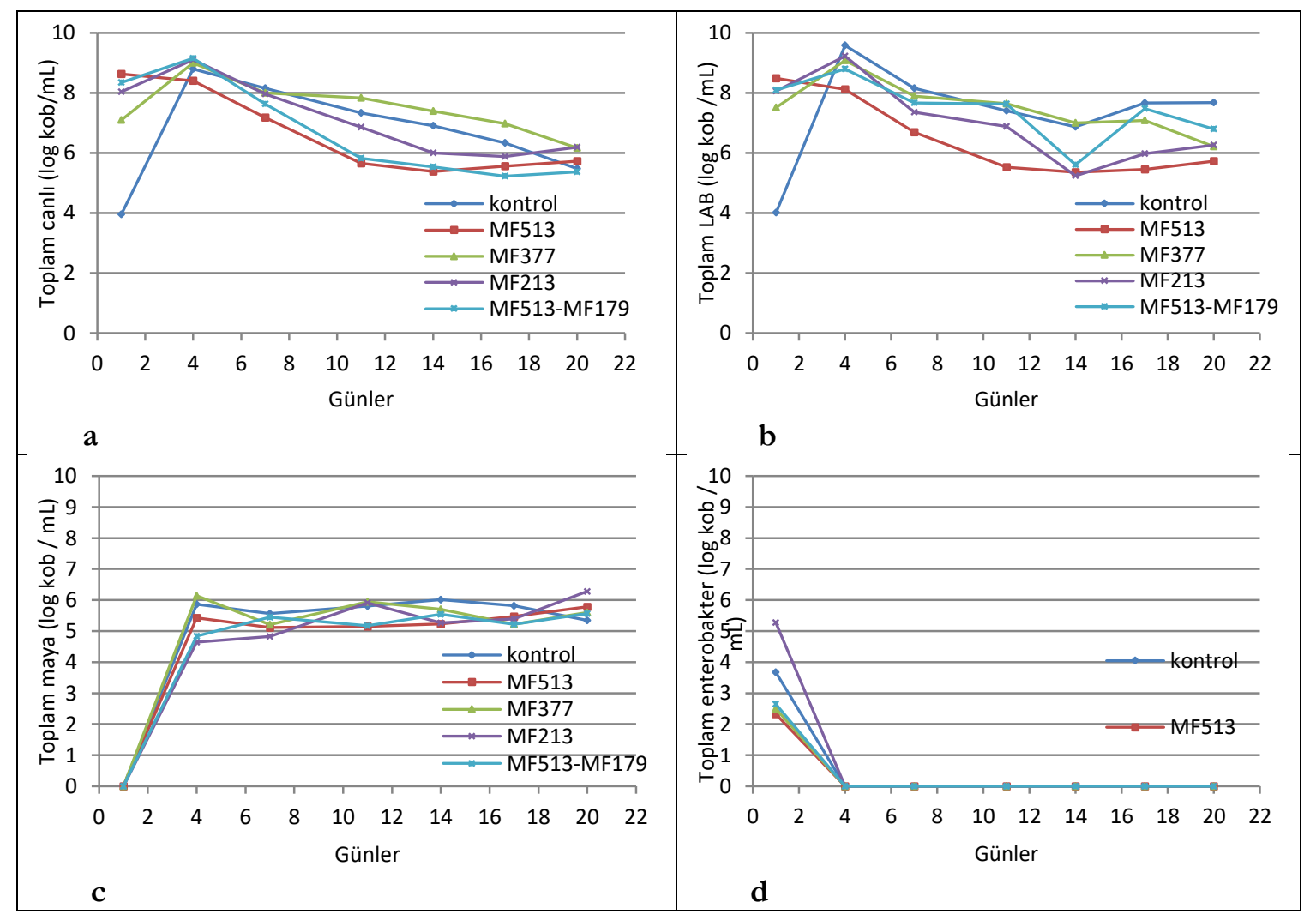

Şekil 1. Fermantasyon süresince salamuradaki mikrobiyolojik sayım sonuçları (log kob/mL) a) Toplam mezofilik aerobik bakteri b) Toplam LAB c) Toplam maya-küf d) Toplam Enterobacteriaceae Figure 1. Results of microbiological counting in brine during fermentation $(\log c f u / m L)$ a) Total mesophilic aerobic bacteria b) Total LAB c) Total yeast-mold d) Total Enterobacteriaceae

Çizelge 2. Fermantasyon sonrası turşuların duyusal değerlendirme sonuçları

Table 2. Results of sensory evaluation of pickles after fermentation

\begin{tabular}{lllllll}
\hline & Görünüş & Renk & Koku & Lezzet & Sertlik & Genel Beğeni \\
\hline kontrol & $4.00 \pm 0.20^{\mathrm{a}}$ & $3.80 \pm 0.08^{\mathrm{a}}$ & $3.74 \pm 0.21^{\mathrm{a}}$ & $3.70 \pm 0.31^{\mathrm{a}}$ & $4.37 \pm 0.47^{\mathrm{ab}}$ & $3.71 \pm 0.29^{\mathrm{ab}}$ \\
MF513 & $4.00 \pm 0.29^{\mathrm{a}}$ & $3.78 \pm 0.36^{\mathrm{ab}}$ & $3.53 \pm 0.64^{\mathrm{a}}$ & $3.56 \pm 0.68^{\mathrm{ab}}$ & $4.35 \pm 0.18^{\mathrm{a}}$ & $3.61 \pm 0.72^{\mathrm{ab}}$ \\
MF377 & $4.11 \pm 0.35^{\mathrm{a}}$ & $4.13 \pm 0.17^{\mathrm{b}}$ & $4.11 \pm 0.29^{\mathrm{a}}$ & $3.93 \pm 0.26^{\mathrm{a}}$ & $4.33 \pm 0.32^{\mathrm{ab}}$ & $3.97 \pm 0.29^{\mathrm{a}}$ \\
MF213 & $3.96 \pm 0.10^{\mathrm{a}}$ & $3.81 \pm 0.20^{\mathrm{ab}}$ & $3.74 \pm 0.10^{\mathrm{a}}$ & $3.30 \pm 0.03^{\mathrm{b}}$ & $4.07 \pm 0.06^{\mathrm{b}}$ & $3.42 \pm 0.08^{\mathrm{b}}$ \\
MF513-MF179 & $4.02 \pm 0.50^{\mathrm{a}}$ & $3.83 \pm 0.25^{\mathrm{ab}}$ & $3.80 \pm 0.37^{\mathrm{a}}$ & $3.78 \pm 0.43^{\mathrm{a}}$ & $4.13 \pm 0.22^{\mathrm{ab}}$ & $3.60 \pm 0.47^{\mathrm{ab}}$ \\
\hline
\end{tabular}

*abc: İstatistiksel olarak aynı sütundaki veriler arasındaki benzerlik $(P<0.05)$ 


\section{Starter Kültürlerin Stabiliteleri}

Turşu örneklerine ilave edilen starter kültürlere ait hücre protein profilleri (Şekil 2), MF513, MF377 ve MF213 suşları kullanılarak hazırlanan turşu fermantasyonlarının bitiminde izole edilen hücrelerin protein profilleri (Şekil 3) ile uyum içerisindedir. Yapılan çalışmada L. plantarum suşlarına ait protein bantlarının daha az sayıda ve silik olduğu görülmektedir. L. plantarum suşlarının pH 3.1 ile 3.5 arasında değişen yüksek asit tolerans1, bu bakterileri turşu üretimi için starter kültür olarak uygun türler haline getirmektedir (Di Cagno vd., 2013). Bu nedenle, L. plantarum genellikle çoğu sebze fermantasyonunun sonunda baskın konumdadır (Mäkimattila vd., 2011). Ancak, MF513-MF179 nolu turșu örneklerinden fermantasyon sonunda, MF179 numaralı starter kültüre ait bakteri protein profiline sahip sadece 3 bakteri izole edilirken, diğer 17 izolatın MF513 numaralı kültüre ait protein profiline sahip olduğu belirlenmiştir. Bu durum, P. ethanolidurans MF179 suşunun fermantasyon sonuna kadar stabilitesini çok iyi koruyamadığı sonucunu göstermektedir.
Tokatlı vd. (2017) tarafından bu suşlara ait teknolojik özelliklerin incelendiği çalışmada $P$. ethanolidurans MF179 suşunun yüksek asitlik ve tuz şartlarında MF513 numaralı suşa göre daha zayıf bir gelişme göstermesi bulduğumuz sonucu destekler niteliktedir. Kamdee vd. (2014) bitkisel fermente ürünlerin üretiminde Weissella spp. ve $L$. fermentum suşlarını starter kültür olarak kullandıkları çalışmada, ürünlerin fermantasyon süresince starter kültür florasındaki değişimini rep-PCR tekniği ile izlemişlerdir. Yaptıkları çalışmada farklı inokulasyon oranlarında starter kültür kullanarak üretimini gerçekleştirdikleri ürünlerde fermantasyonun başlangıç aşamalarında Weissella spp. türünün predominant floray1 oluşturduğunu, ancak daha sonra hızlı bir şekilde 3. günden itibaren floranin $L$. fermentum ve $L$. plantarum lehine değiştiğini belirlemişlerdir. Benzer şekilde, diğer bazı çalışmalarda da fermantasyon sonunda ürünlerde dominant florayı L. plantarum suşlarının oluşturduğu belirtilmektedir (Nguyen vd., 2013).
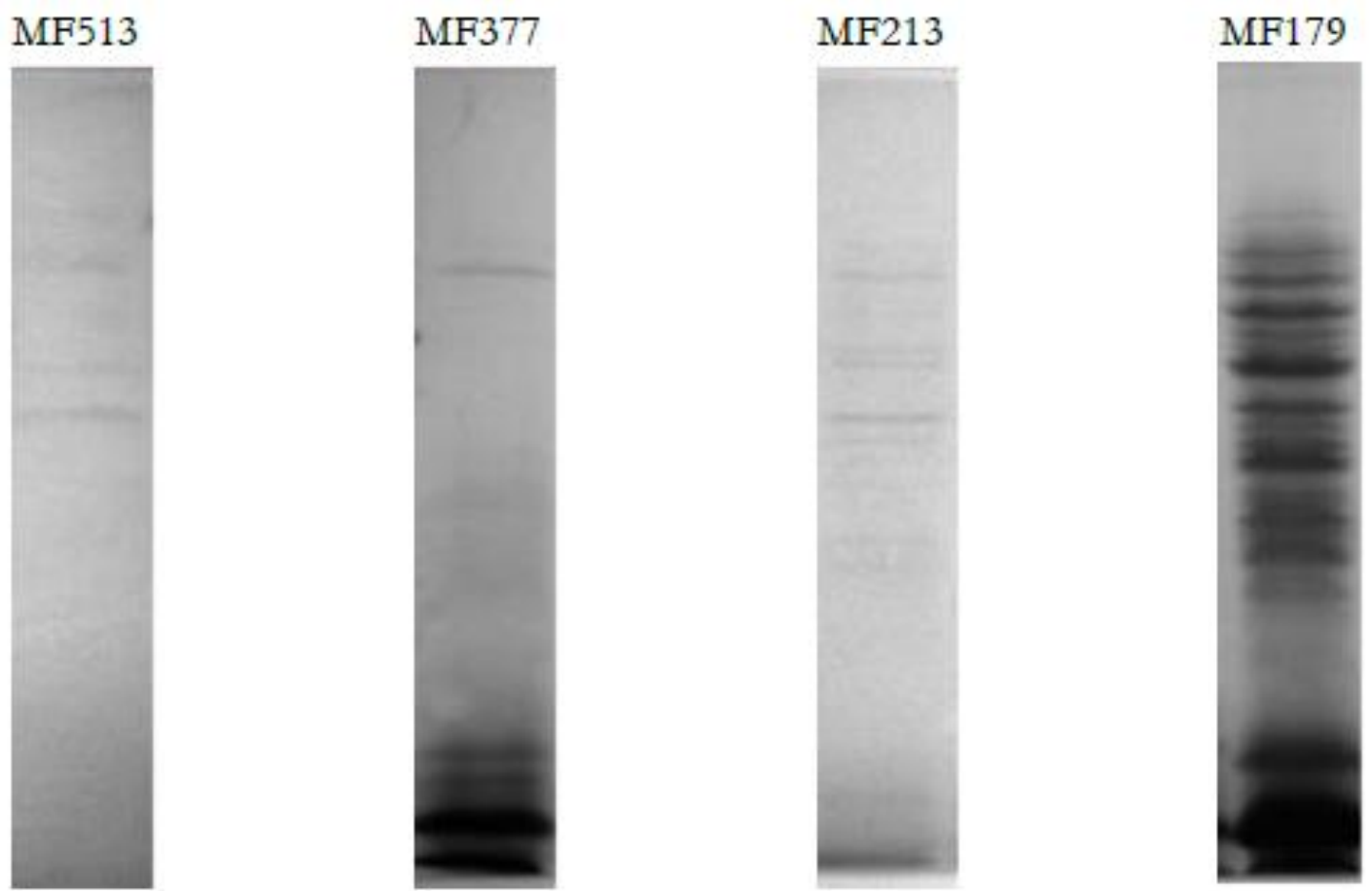

Şekil 2. Starter kültür olarak kullanılan suşlara ait hücre protein profilleri (SDS-PAGE)

Figure 2. Whole cell protein profiles of $L A B$ strains used as starter culture (SDS-PAGE) 


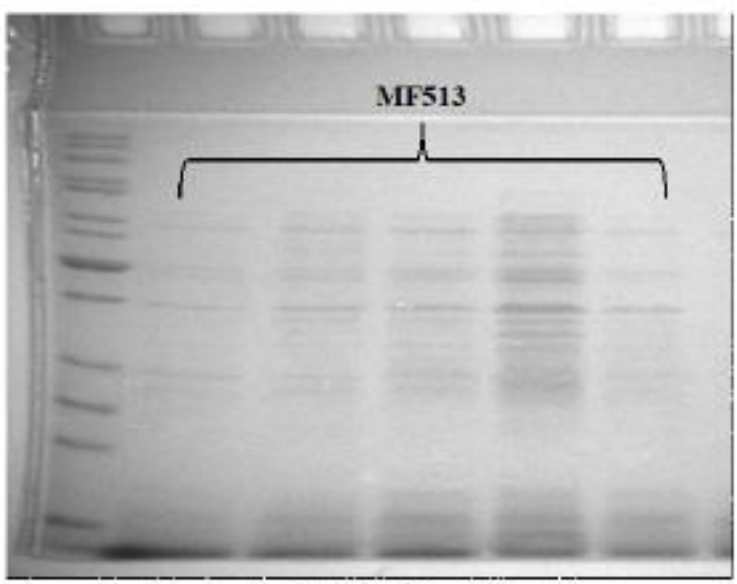

MF513

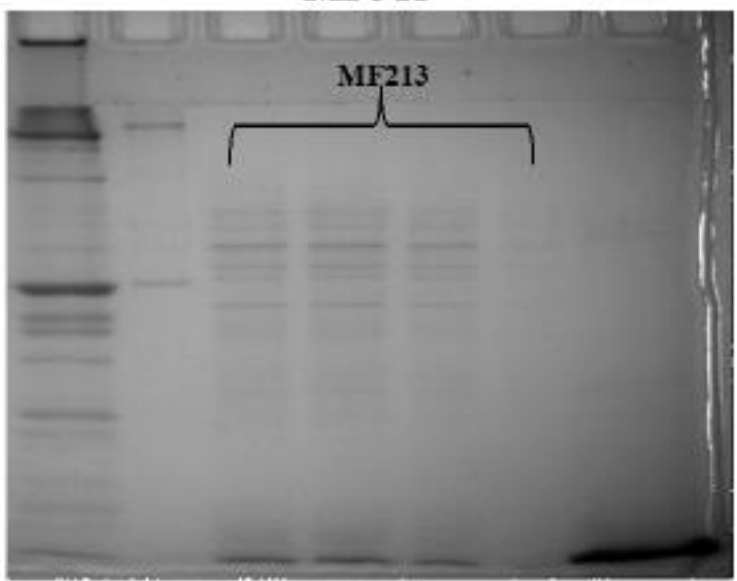

MF213

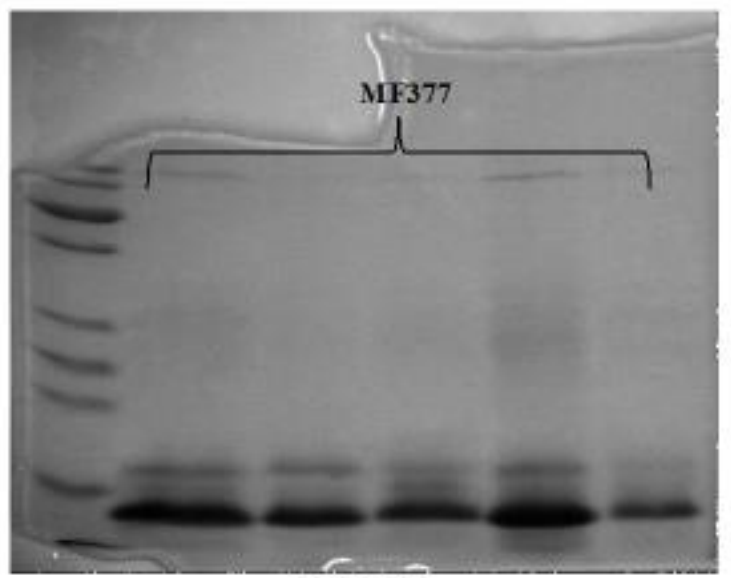

MF377

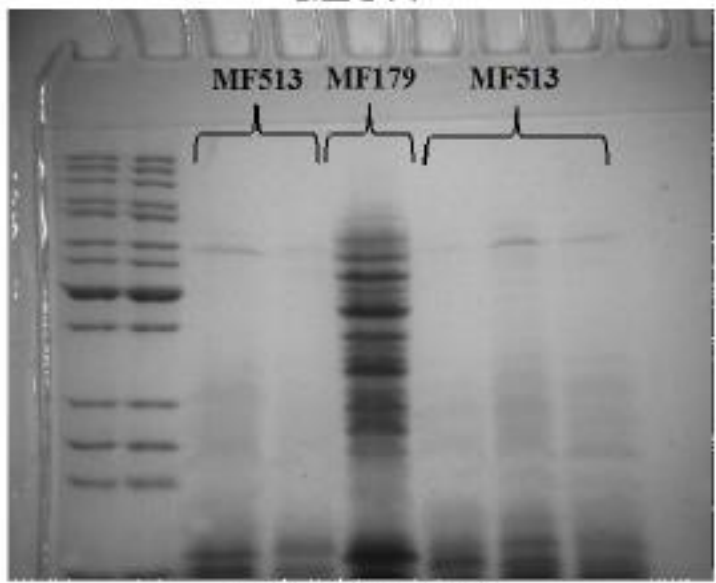

MF513-MF179

Şekil 3. Starter kültürler ile üretilen turşu örneklerinden izole edilen laktik asit bakterilerine ait hücre protein profilleri (SDS-PAGE)

Figure 3. Whole cell protein profiles of lactic acid bacteria isolated from pickle samples produced by starter cultures (SDS-PAGE)

\section{Depolama}

Depolama amacı ile üretimi gerçekleştirilen turşu gruplarından elde edilen veriler ile fermantasyon denemesinde üretilen turşulardan elde edilen veriler arasında bir ilişki veya bağıntı kurulması amaçlanmamış olup, tamamen ayrı bir deneme olarak düşünülmüştür. İki deneme arasındaki benzerlik, yalnızca aynı bileşimdeki salamuraların ve araştırma materyali olarak aynı özellikteki hıyarların kullanılması olarak kalmıştır. Depolama denemesi sırasında elde edilen değerler, farklı salamuralardan ve farklı depolama süreleri sonucu elde edilen kimyasal analizlerin ortalama deneysel sonuçları, Şekil 4' te verilmiştir.
Gerçekleştirilen depolama denemelerine ait $\mathrm{pH}$ sonuçları incelendiğinde (Şekil 4a) 2 aylık depolamaya alınan örneklerde en yüksek $\mathrm{pH}$ değeri kontrol örneğinde 3.51, en düşük değer ise MF513-MF179 nolu örnekte 3.30 olarak saptanmıştır. MF513, MF377 ve MF213 nolu örnek salamuralarının $\mathrm{pH}$ değerleri ise birbirine benzer bulunmuştur ( $\mathrm{pH}$ 3.41). 4 aylik ve 6 aylik depolama örneklerinde benzer şekilde en düşük pH değeri MF513-MF179 nolu örnekte, sirasıyla 3.27 ve 3.21 olarak belirlenmiştir.

Depolanan örneklerde titrasyon asitliği değerleri (Şekil 4b) incelendiğinde, 2 aylık depolamaya alınan örneklerde en yüksek titrasyon asitliği 
değeri MF513-MF179 nolu karsş1k kültür ile fermente edilen örnekte \% 1.28 olarak, en düşük değer ise MF377 nolu örnekte \% 1.01 olarak saptanmıştır. MF513, MF213 ve kontrol örneklerinde ortalama titrasyon asitliği değeri 1.05 olarak bulunmuştur. $\mathrm{Bu}$ çalışmada ulaşılan titrasyon asitliğine ait sonuçlar ile Etchells ve ark. (1975)' in 3 ay depolama sonucu belirttiği ortalama \% 0.60-1.46 değerleri arasinda benzerlik bulunmaktadır. 4 aylık depolamaya alınan örneklerde en yüksek titrasyon asitliği değeri MF513-MF179 nolu karış1k kültür ile üretilen turşularda \% 1.34; en düşük titrasyon asitliği ise MF377 nolu örnekte \% 1.02 olarak bulunmuştur. 6 aylık depolamaya alınan örneklerde en yüksek titrasyon asitliği değeri MF513-MF179 nolu örnekte \% 1.46; en düşük değer ise MF513 nolu örnekte \% 1.10 olarak belirlenmiştir. 2, 4 ve 6 aylik depolama örneklerine ait salamuraların tümü incelendiğinde, en yüksek titrasyon asitliği değeri, ortalama \% 1.26 ile 6 aylık turşularda, en düşük değer ise ortalama \% 1.09 ile 2 aylık turşu örneklerinde ortaya çıkmıştır.

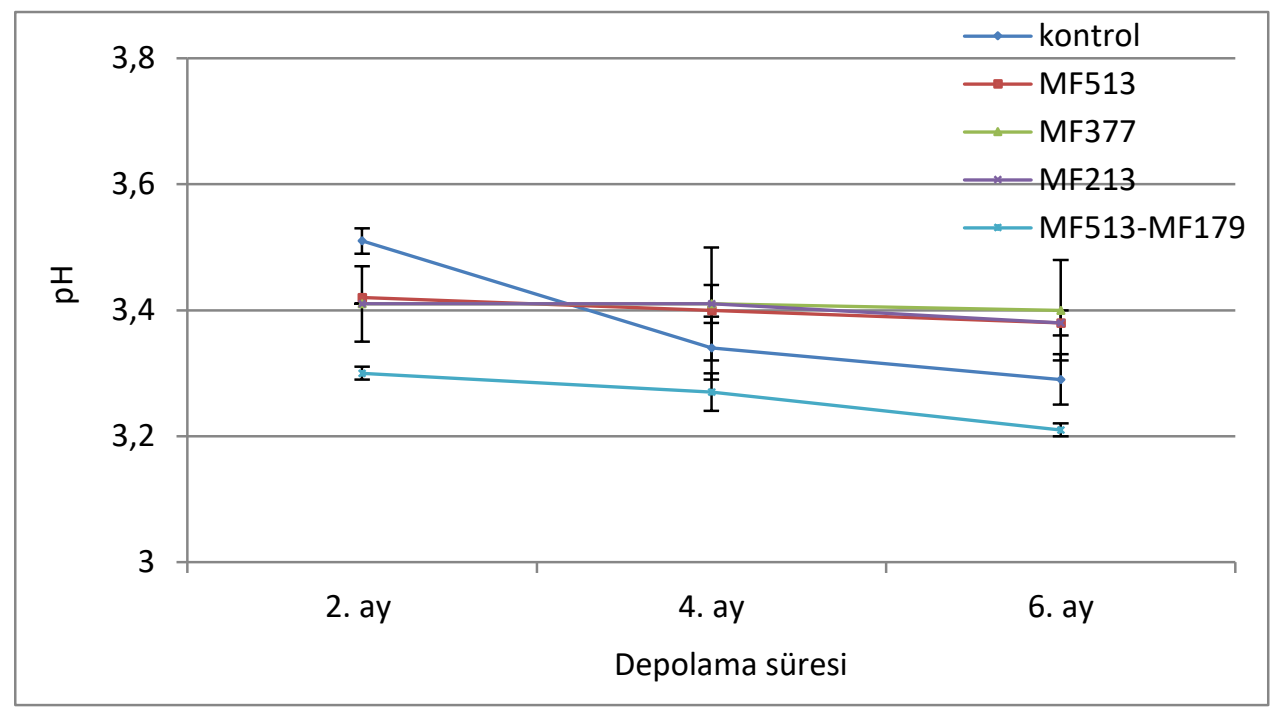

a

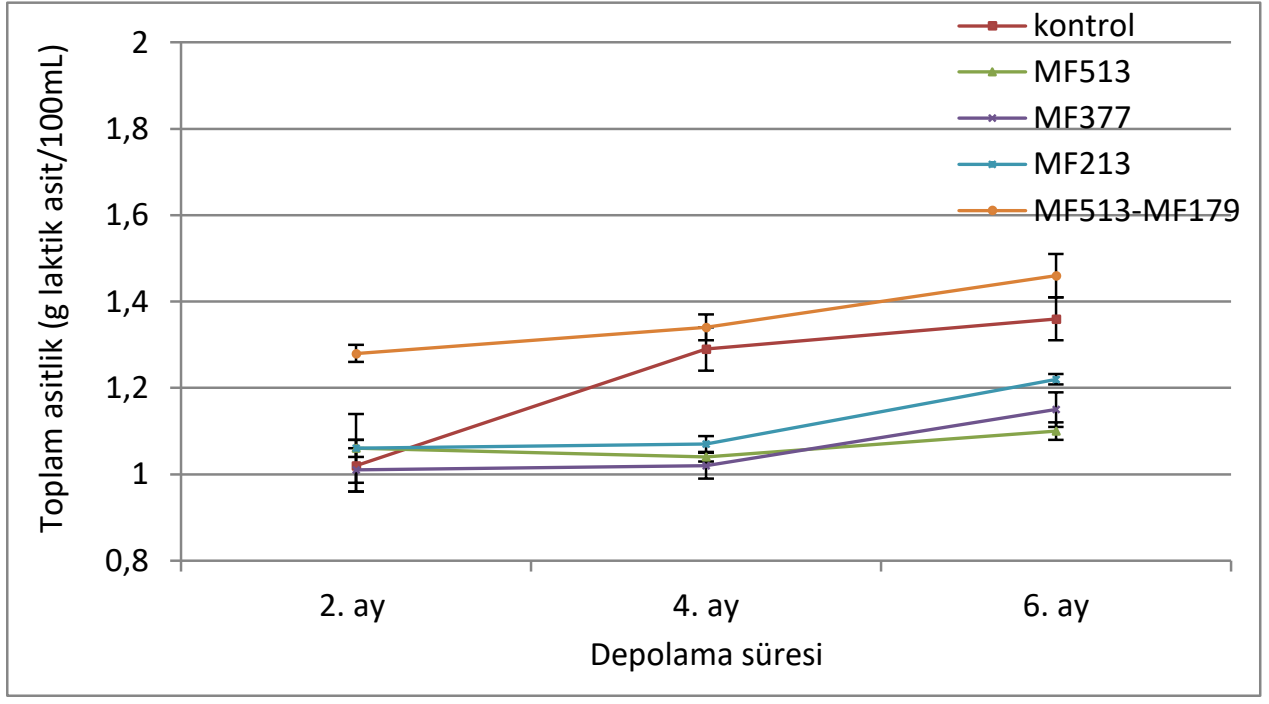

b 


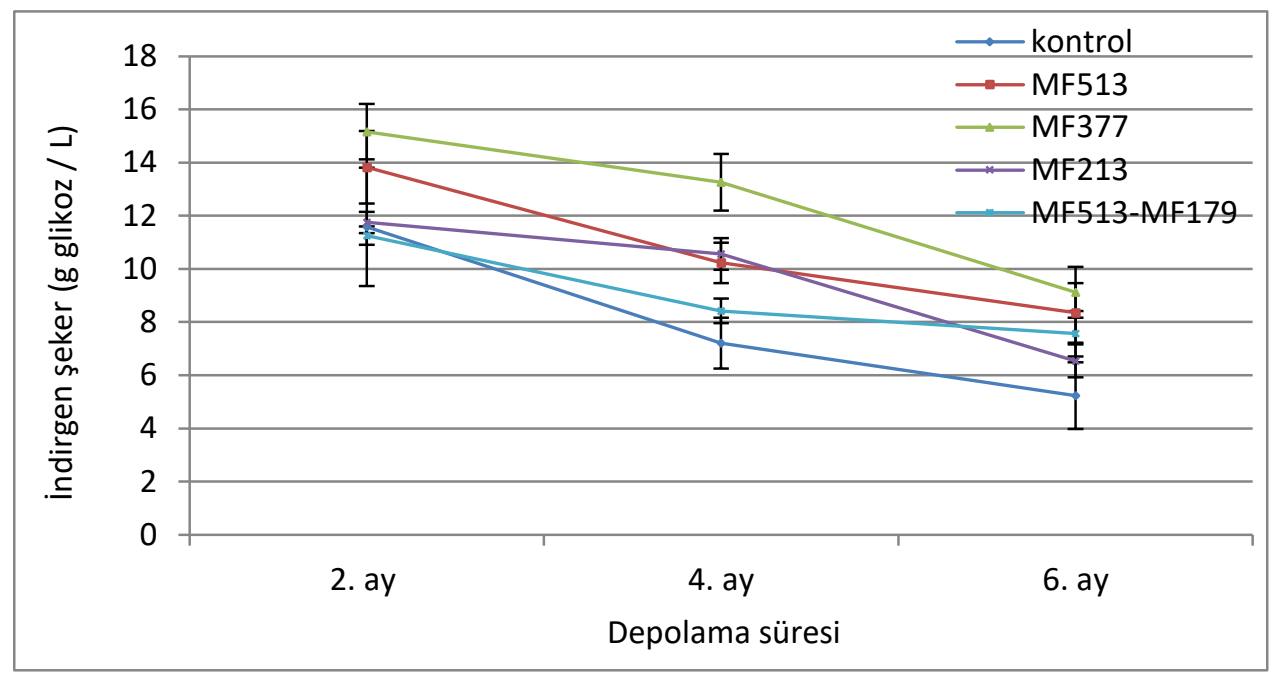

C

Şekil 4. Depolama süresince salamura örneklerinde a) pH, b) titrasyon asitliği ve c) indirgen şeker değişimleri

Figure 4. Changes in brine samples during storage a) $p H$, b) titratable acidity and c) reducing sugar

2 aylık depolanan örneklere ait indirgen şeker miktarlarının ise MF377 ve MF513 nolu örnekte en yüksek değerde (15.16 ve $13.82 \mathrm{~g} / \mathrm{L})$ bulunduğu, ancak diğer örneklerde de kalan şeker miktarının da oldukça yüksek değerlerde olduğu görülmektedir. 4 ve 6 aylık depolanan örneklerde ise daha düşük miktarlarda indirgen şeker belirlenmiş̧ir (Şekil 4c). Fermantasyon sonunda kalan şeker düzeyinin bu denli yüksek olması, muhtemelen şeker dışında diğer indirgen maddelerden kaynaklandığı düşünülmektedir.

Depolama denemesi sirasinda farklı salamuralardan elde edilen mikrobiyel sayımların ortalama sonuçları, Şekil 5'te verilmiştir. LAB sayısı 2 aylık örneklerde en fazla $6.05 \mathrm{log} \mathrm{kob} / \mathrm{mL}$ ile MF213 nolu örnekte, en az $3.27 \mathrm{log} \mathrm{kob} / \mathrm{mL}$ ile MF513-MF179 nolu örnekte bulunmuştur. Toplam mezofil bakteri sayısı 2 aylık örneklerde toplam LAB sayısında olduğu gibi en yüksek MF213 nolu örnekte, en düşük ise MF513-MF179 nolu örnekte tespit edilmiştir. Örneklerdeki toplam maya sayıs ise $\log 3.17-4.91 \mathrm{kob} / \mathrm{mL}$ aralığında bulunmuş olup en yüksek maya içeriği MF377 nolu örnekte saptanmıştır. Araştırmamızda elde edilen bu sonuçlara göre, LAB populasyonunun depolama süresince, sayıları azalsa da, aktif kaldığı söylenebilir. Karışık starter kültürler kullanılarak üretilen ve depolanan MF513-MF179 kodlu örneklerin maya, LAB ve toplam mezofil mikrobiyel yükünün diğer örneklere kıyasla daha düşük olması, bu turşu örneğinin daha yüksek asitlik ve düşük $\mathrm{pH}$ değeri ile de ilişkilendirilmiştir.

Depolama sonrası turşu örneklerinin şeker, organik asit kompozisyonu ve etil alkol oranlar1

Fermantasyon sırasında ve depolama aşamasında şeker ve organik asit kompozisyonlarının ve bunların miktarlarının belirlenmesi, fermantasyonda etkin bakteri grubunun belirlenebilmesi açısından bir yorum yapabilmeye olanak sağlayabilir. Örneklerin depolama sonunda HPLC ile şeker ve organik asit kompozisyonları belirlenmiş, bunlara ilaveten etil alkol miktan da saptanmış; sonuçlar, 3 paralelin ortalaması olarak, Çizelge 3'te verilmiştir. Starter kültür kullanılan turşu örnekleri ile kontrol grubuna ait örnekte 6 . ay depolama sonunda asetik asit miktarları benzer bulunmuş ve ortalama $0.26 \mathrm{~g} / 100 \mathrm{~mL}$ olarak belirlenmiştir $(P \quad>0.05)$. Fermantasyon denemelerinde elde edilen toplam asitlik sonuçlarında olduğu gibi depolama sonrası en 
yüksek laktik asit miktar1 MF513-MF179 suşlarının kullanıldığı turşu örneğinde belirlenmiş ve kontrol grubu turşu örneğinde benzer şekilde daha yüksek laktik asit miktarı ölçülmüştür ( $P$ $>0.05)$. En düşük laktik asit miktarı ise MF213 nolu turşu örneğinde belirlenmiş olup, $1.09 \mathrm{~g}$ laktik asit/100 mL olarak ölçülmüştür. Turşu örneklerinin 6 ay depolama sonrasi kalan şekerlerin kompozisyonu incelenecek olursa, tüm örneklerin fruktoz miktarı glikoza kıyasla daha düşük belirlenmiştir. Özellikle 6. ay depolama sonunda laktik asit miktarı daha yüksek ölçülen MF513-MF179 nolu örnekte kalan fruktoz miktarının daha düşük olduğu görülmektedir. Bu durumun, karışık kültür fermantasyonunda yer alan $L$. plantarum ve $P$. ethanolidurans suşlarının farklı şeker fermantasyon profiline sahip olması ile ilişkili olduğu düşünülmektedir. Tüm turşu örneklerinde depolama sonrası kalan glikoz miktarlar1 ise benzer olarak bulunmuştur $(P$ $>0.05$ ). Fermantasyon sonrası oluşan ve ortamda kalan etil alkol miktarları incelenecek olursa, en yüksek alkol MF213 nolu örnekte $0.48 \mathrm{~g} / 100 \mathrm{~mL}$ olarak ölçülmüss olup, kontrol ve MF513 nolu örneklerde de benzer alkol miktarları belirlenmiştir. Yüksek alkol miktarları fermantasyonda kullanılan şekerlerin asit oluşumu ile birlikte alkol üretimine harcandığının göstergesi olmaktadır. Fermantasyon ortamında bulunan maya hücreleri alkol üretiminde temel sorumlu florayı oluşturmaktadır. Depolama sonras1 MF213 nolu turșu örneğinde ölçülen düşük laktik asit miktarı ve maya yükü bu sonuçları destekler niteliktedir.
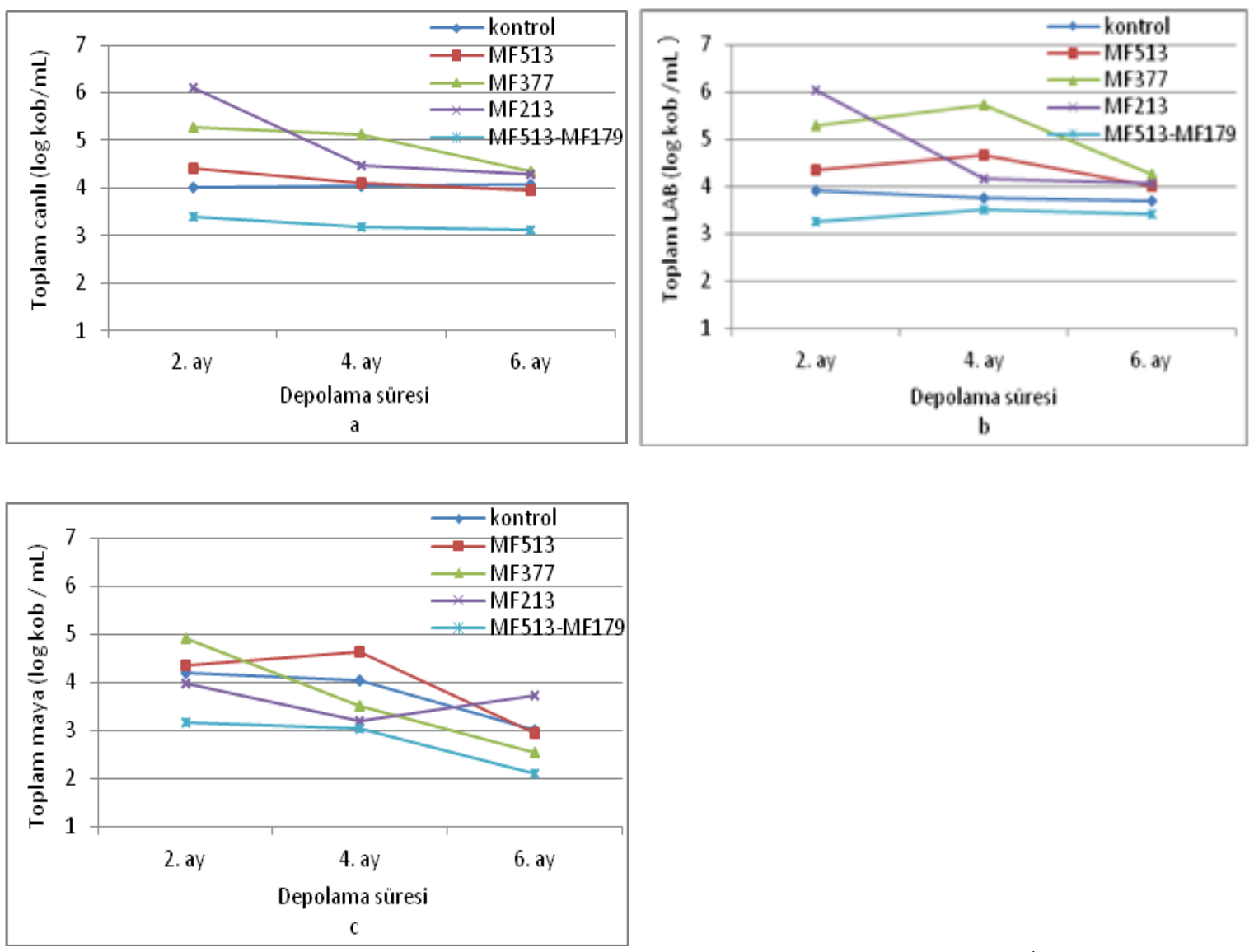

Şekil 5. Depolama süresince salamuradaki mikrobiyolojik sayım sonuçları (log kob/mL) a) Toplam mezofilik aerobik bakteri b) Toplam LAB c) Toplam maya-küf

Figure 5. Results of microbiological counting in brine during storage $(\log c f u / m L)$ a) Total mesopbilic aerobic bacteria b) Total $L A B$ c) Total yeast-mold 
Çizelge 3. 6 ay süre ile depolanan turşu örneklerine ait şeker, organik asit dağılımı ve etil alkol miktarları $(\mathrm{g} / 100 \mathrm{~mL})$

Table 3. Sugar, organic acid distribution and ethyl alcohol content $(\mathrm{g} / 100 \mathrm{~mL})$ of pickle samples stored for 6 months

\begin{tabular}{lccccc}
\hline & Fruktoz & Glikoz & Etanol & Asetik asit & Laktik asit \\
\hline Kontrol & $0.10 \pm 0.12^{\mathrm{ab}}$ & $0.44 \pm 0.26^{\mathrm{a}}$ & $0.37 \pm 0.14^{\mathrm{ab}}$ & $0.26 \pm 0.01^{\mathrm{a}}$ & $1.49 \pm 0.43^{\mathrm{abc}}$ \\
MF513 & $0.21 \pm 0.05^{\mathrm{a}}$ & $0.60 \pm 0.16^{\mathrm{a}}$ & $0.38 \pm 0.10^{\mathrm{ab}}$ & $0.25 \pm 0.00^{\mathrm{a}}$ & $1.29 \pm 0.11^{\mathrm{b}}$ \\
MF377 & $0.20 \pm 0.15^{\mathrm{a}}$ & $0.74 \pm 0.10^{\mathrm{a}}$ & $0.27 \pm 0.02^{\mathrm{b}}$ & $0.25 \pm 0.00^{\mathrm{a}}$ & $1.34 \pm 0.23^{\mathrm{bc}}$ \\
MF213 & $0.16 \pm 0.04^{\mathrm{a}}$ & $0.55 \pm 0.16^{\mathrm{a}}$ & $0.48 \pm 0.11^{\mathrm{a}}$ & $0.26 \pm 0.02^{\mathrm{a}}$ & $1.09 \pm 0.04^{\mathrm{c}}$ \\
MF513-MF179 & $0.02 \pm 0.01^{\mathrm{b}}$ & $0.74 \pm 0.08^{\mathrm{a}}$ & $0.26 \pm 0.02^{\mathrm{b}}$ & $0.26 \pm 0.00^{\mathrm{a}}$ & $1.62 \pm 0.02^{\mathrm{ab}}$ \\
\hline
\end{tabular}

*abc: İstatistiksel olarak aynı sütundaki veriler arasındaki benzerlik $(P<0.05)$

\section{SONUÇ}

Starter kültür kullanılarak üretilen turşularda duyusal olarak belirgin bir üstünlük belirlenememesine karşın, laktik asit fermantasyonunu kısa sürede tamamlamış olmaları nedeniyle, starter kullanımının fermantasyonun seyrine önemli bir katkıda bulunduğu anlaşılmaktadır. Turşu üretiminde starter kullanımı, fermantasyonun güvenle tamamlanmasina ve standart özelliklere sahip ürün oluşumuna verdiği katk1 nedeniyle, üreticilere tavsiye edilebilir. Yapılan bu çalışma ile tanımlanmış ve karakterize edilmiş starter kültürler tarafindan turşu fermantasyonlarının daha kontrollü ve güvenilir bir şekilde yürütülmesi sağlanarak, endüstriyel turşu üretimleri için kaynak oluşturması hedeflenmiştir. Özellikle karışı starter kültürlerin fermantasyonlarda kullanımı her bir kültürün sahip olduğu farklı teknolojik özelliklerin bir arada kullanımına firsat verecektir. Spontan fermantasyonlardaki en büyük sorun olan standardizasyon ve ürün güvenliği bu şekilde daha iyi sağlanabilecektir.

\section{TEŞEKKÜR}

$\mathrm{Bu}$ çalışma, Türkiye Bilimsel ve Teknolojik Araştırma Kurumu (TÜBİTAK) (Proje No. 108O491) tarafindan desteklenen projenin bir bölümüdür.

\section{KAYNAKLAR}

Akpinar-Bayizit, A., Ozcan-Yilsay, T., Yilmaz, L. (2007). Study on the use of yoghurt, whey, lactic acid and starter culture on carrot fermentation. Pol. J. Food. Nutr. Scl., 57(2): 147150.
Angelis, M., Corsetti, A., Tosti, N., Rossi, J., Corbo, M.R., Gorbetti, M. (2001). Characterization of non-starter lactic acid bacteria from Italian ewe cheeses based on phenotypic, genotypic, and cell wall protein analyses. Appl. Environ. Microbiol., 67(5): 2011-2020.

Bağder Elmacı, S., Tokatlı, M., Dursun, D., Özçelik, F., Şanlıbaba, P. (2015). Phenotypic and genotypic identification of lactic acid bacteria isolated from traditional pickles of the Çubuk region in Turkey. Folia Microbiol, 60: 241-251.

Breidt, F., McFeeters, R. F., Perez-Diaz, I., Lee, C. (2013). Fermented vegetables. In Food Microbiology: Fundamentals and Frontiers. Doyle, M.P., Buchanan, R.L. (Ed.), ASM Press, Washington D.C., pp. 841855.

Çetin, B. (2011). Production of probiotic mixed pickles (Turşu) and microbiological properties. Afr. J. Biotechnol., 10(66): 14926-14931.

Çon, A.H., Karasu, N. (2009). Determination of antogonostic starter cultures for pickle and olive fermentation processes. Cžech. J. Food. Sci., 27(3): 185-193.

Daeschel, M.A., Fleming, H.P. (1984). Selection of lactic acid bacteria for use in vegetable fermentations. Food Microbiol., 1: 303-313.

Di Cagno, R., Coda, R., De Angelis, M., Gobbetti, M. (2013). Exploitation of vegetables and fruits through lactic acid fermentation. Food Microbiol., 33(1): 1-10.

Erten, H., Boyac1-Gündüz, C.P., Ağırman, B., Cabaroğlu, T. (2016). Fermentation, Pickling, and Turkish Table Olives. In: Handbook of Vegetable 
Preservation and Processing, Hui, Y.H., Evranuz, E.Ö., Bingöl, G., Erten, H., Jaramillo-Flores, M.E. CRC Press, Taylor\&Francis Group, Boca Raton, pp. 209-230.

Etchells, J.L., Fleming, H.P., Bell, T.A. (1975). Factor influencing the growth of lactic acid bacteria during brine fermentation of cucumbers; Lactic Acid Bacteria in Beverages and Food. Carr, J.G., Cutting, C.V., Whiting G.C. (Ed), Academic Press, New York, pp. 281-305.

Forouchi, E., Gunn, D.J. (1983). Some effects of metal ions on the estimation of reducing sugars in biological media. Biotechnol. Bioeng., 25: 1905-1911.

Gardner, N.J., Savard, T., Obermeier, P., Caldwell, G., Champagne, C.P. (2001). Selection and characterization of mixed starter cultures for lactic acid fermentation of carrot, cabbage, beet and onion vegetable mixtures. Int. J. Food Microbiol., 64: 261-275.

Gürgün, V., Halkman, A.K. (1988). Mikrobiyolojide sayım yöntemleri. Gida Teknolojisi Derneği, Ankara, $146 \mathrm{~s}$.

Holzapfel W. (2014) Advances in fermented foods and beverages: improving quality, technologies and health benefits. Woodhead Puplishing, Elsevier, 541p.

Hutkins, R.W. (2006). Microbiology and Technology of Fermented Foods. Blackwell Publishing, USA, pp.233-259.

Kamda, A.G.S., Ramos, C.L., Fokou, E. (2015). In vitro determination of volatile compound development during starter culture controlled fermentation of Cucurbitaceae cotyledons. Int. J. Food Microbiol., 192: 58-65.

Kamdee, S., Plengvidhya, V., Chokesajjawatee, N. (2014). Changes in lactic acid bacteria diversity during fermentation of sour pickled mustard green. KKU Res. J., 19: 26-33.

Karasu, N., Şimşek, Ö., Çon, A.H. (2010). Technological and probiotic characteristics of Lactobacillus plantarum strains isolated from traditionally produced fermented vegetables. Ann. Microbiol., 60: 227-234.

Kim, Y., Adachi, Y. (2007). Biological and genetic classification of canine intestinal lactic acid bacteria and bifidobacteria. Mic. Immunol., 51: 919928.

Laemmli, U.K. (1970). Cleavage of structural proteins during the assembly of the head of bacteriophage T4. Nature, 227: 680-685.

Mäkimattila, E., Kahala, M., Joutsjoki, V. (2011). Characterization and electrotransformation of Lactobacillus plantarum and Lactobacillus paraplantarum isolated from fermented vegetables. World J. Microbiol. Biotechnol., 27: 371-379.

Montet, D., Ray, R.C., Zakhia-Rozis, N. (2014). Lactic Acid Fermentation of Vegetables and Fruits. In Microorganisms and fermentation of traditional foods. Ray, R.C., Montet, D. (Ed.), CRC Press., pp. 108140.

Nguyen, D.T., Van Hoorde, K., Cnockaert, M., De Brandt, E., Aerts, M., Binh Thanh, L., (2013). A description of the lactic acid bacteria microbiota associated with the production of traditional fermented vegetables in Vietnam. Int. J. Food. Microbiol., 163(1): 19-27.

Nilchian, Z., Sharifan, A., Rahimi, E., Mazid Abadi, N. (2016). Improvement of fermented cucumber characteristics by starter culture of Lactobacillus plantarum, L. bulgaricus and $S$. thermophiles. J. Food Biosci. Technol., 6(2): 31-40.

Özer, C., Kalkan Yıldırım H. (2018). Production of pickles by mixed culture fermentation. The American J. of Chem. and App., 5: 57-68.

Peréz-Díaz, I.M., Breidt, F., Buescher, R.W., Arroyo-López, F.N., Jiménez-Diaz, R., GarridoFernández, A., Johanningsmeire, S.D. (2013). Fermented and acidified vegetables. Compendium of methods for the microbiological examination of foods, American Public Health Association, Washington DC, pp. 521-532.

Shinagawa, H., Nishiyama, R., Miyao, S., Kozaki, M. (1997). Organic acid composition and quality of Japanese "shibazuke" pickles. Food Sci. Technol. Int. Tokyo, 3(2): 170-172.

Swida, K.M., Binek, M. (2005). Selection of potentially probiotic Lactobacillus strains towards their inhibitory activity against poultry enteropathogenic bacteria. Polish J. of Mic., 54: 287294. 
Tokatlı, M., Dursun, D., Arslankoz, N., Şanlıbaba, P., Özçelik, F. (2012). Turşu üretiminde laktik asit bakterilerinin önemi. Akademik Gıda, 10(1): 7076.

Tokatlı, M., Elmacı, S.B., İşleyen, N.A., Özçelik, F. (2017). Technological properties of lactic acid bacteria isolated from traditional pickles. The Journal of Food, 42(6): 693-707.

Tokatlı, M., Gülgör, G., Bağder Elmacı, S., Arslankoz İşleyen, N., Özçelik, F. (2015). In vitro properties of potential probiotic indigenous lactic acid bacteria originating from traditional pickles. Biomed Res. Int., 1-8.

Tomlins, K.I., Baker, D.M., McDowell, I.J. (1990). HPLC method for the analysis of organic acids, sugars, and alcohol in extracts of fermenting cocoa beans. Chromatographia, 29(1112): $557-561$.

Wu, C., Zheng, J., Huang, J., Zhou, R. (2014). Reduced nitrite and biogenic amine concentrations and improved flavor components of Chinese sauerkraut via co-culture of Lactobacillus plantarum and Zygosaccharomyces rouxii. Ann. Microbiol., 64: 847-857.

Xia, Y., Liu, X., Wang, G., Zhang, H., Xiong, Z., Sun, Y., Ai, L. (2017). Characterization and selection of Lactobacillus brevis starter for nitrite degradation of Chinese pickle. Food Control, 78: 126-131. 